\title{
ANALYSIS OF MARINE ACCIDENTS INVOLVING CONTAINER
} SHIPS

\section{АНАЛІЗ МОРСЬКИХ АВАРІЙ ЗА УЧАСТЮ КОНТЕЙНЕРОВОЗІВ}

\author{
N. Konon, Ph.D. student, O. Pipchenko, associate professor, D.Sc. \\ Н.М. Конон, аспірантка, О.Д. Піпченко, д.т.н., доиент \\ National University “Odessa Maritime Academy”, Ukraine \\ Національний Університет «Одеська Морська Академія», Украӥна
}

\begin{abstract}
The research presents the analysis of statistics of the marine accidents involving container vessels, based on 22 marine accident investigation reports covering the period from 2012 to 2019. The analysis is intended to become the basis for specifying the key factors which affect the underestimation of risk assessment in the course of navigation of container vessels. Although the existing negative experience is set out in the investigation reports, which contain "case studies" with recommended avoiding actions, the tendancy of maritime accidents and incidents persists.

Marine casualties considered are classified as very serious and serious marine casualties according to IMO Circular MSC-MEPC.3/Circ.3 "Casualty-related matters. Reports on marine casualties and incidents". In order to study the trend of factors leading to marine accidents, the root causes were divided into two groups: primary and secondary. The study looks at the likelihood of several types of accidents within the specified period, defining the collisions as the most prevalent. Based on the correlation of the results, one of the cases was selected to be described in detail. Possible preventive safety measures for the respective marine accidents have been considered, highlighting the vital role of situational awareness at all times.
\end{abstract}

Keywords: container vessels, safety of navigation, serious marine accidents, situational awareness, collision.

\section{PEФЕРАT}

У дослідженні представлено аналіз статистики морських аварій за участю контейнеровозів на основі 22 звітів про розслідування морських аварій за період з 2012 по 2019 роки. Аналіз має стати основою для оцінки ключових факторів, щэо впливають на недооцінку оиінки ризику під час навігації контейнеровозів. Незважаючи на те, щчо наявний негативний досвід викладено у звітах про розслідування, які містять «дослідження» з рекомендованими діями уникнення, тендениія морських аварій та інцииентів зберігається.

Згідно з Циркуляром IMO MSC-MEPC.3/Circ.3 "Casualty-related matters. Reports on marine casualties and incidents», розглянуті морські аварії класифікуються як дуже серйозні та серйозні морські аваріі. Звіти про морські жертви та інциценти». 3 метою вивчення тенденції факторів, щчо призводять до морських аварій, першопричини були розділені на дві групи: первинні та вторинні. Дослідження оцінює ймовірність кількох видів аварій протягом зазначеного періоду, визначаючи випадки зіткнення як найбільш поширені. На основі кореляиї результатів було обрано один із випадків для детального опису. Розглянуто можливі запобіжні заходи безпеки для відповідних морських аварій, підкреслюючи життєву роль усвідомлення безпеки в будь-який час.

В результаті дослідження аварійності контейнеровозів за період з 2012 по 2019 роки, було визначено, що найбільш поширеною морською аварією в межах аналізу постає зіткнення суден. Крім того, зазначено, щуо неусвідомленість ситуацї при иьому переважає як первинна $i$ вторинна причини в більшості випадків. Вивчивщи рекомендачіï, надані у звітах про 
розслідування аварій, слід підкреслити, щьо вони переважно стосуються навчання, підготовки та перевірки компетентності екіпажу залученого у морську аварію.

Дані, надані звітами про морські дослідження та щморічними оглядами EMSA, виконують статистичну функиію. Однак головна мета підвищення безпеки судноплавства не може бути досягнута лише иляхом аналізу статистичних даних. Отже, стратегія забезпечення мінімізації аварій на морі має полягати у визначенні першопричин з метою розробки ефективних методів їх запобігання.

Ключові слова: контейнеровози, безпека судноплавства, серйозні морські аварії, ситуаційна обізнаність, зіткнення.

\section{tasks \\ Statement of the problem in general terms and its relationship to scientific and practical}

Over the years, container vessels have confirmed their significant role in the market chain of global logistics. Nowadays, international trade persists in marine transportation of non-bulk cargo in containers [4]. As a result, the shipbuilding industry provides an international fleet with larger container vessels - ULCS. For example, container vessel "Ever Act" launched in September 2021 in South Korea, became already the second ship in a series of 11 ULCS with a declared capacity of about 23,992 TEUs, a length of 400 meters, a width of 62 meters, and a draft of 16,5 meters. However, maritime accidents and incidents, especially those related to container shipping, keep emerging. It could be expected that with the increase in the size of ships, the number of accidents might increase as well. As of today, the problem of navigational safety of ships remains relevant. The intensification of maritime traffic flows, the increase of the cargo amount, the growth of the vessels size, the constant changes in the maritime industry, as well as human error are the factors enhancing the risk of marine accidents. This research presents the analysis of serious marine casualties involving container vessels, based on 22 marine accident investigation reports covering the period from 2012 to 2019. The main objective of this article is to examine the primary and secondary causes leading to the predominant type of accident and, based on one selected case study, to identify appropriate safety precautions.

\section{Analysis of recent advances and publications that have begun to address this problem, and highlighting unresolved issues}

The widely accepted belief is that human error accounts for $80-85 \%$ of the total number of marine accidents throughout the world. Recent research [10] presents the qualitative validation of this fact based on the relevant documents from 2001 to 2020, including references to "human factors, human errors, human element, and human source". According to the results, human contribution to the accidents was found to be $70.2 \%$ in the documents referring to human error and $88.9 \%$ - for human factor reference. However, the author in his work highlights the uncertainty in the definition of the human factor across different approaches and frameworks. Another investigation [5] focused on the effect of the human factor with division into categories. The results of the mentioned work confirmed that the human factor significantly affects the causation of marine accidents. The paper aimed to discover the most common human factor categories with establishing their relationship.

For the purpose of this research, 22 marine accident investigation reports [9, 11], involving container vessels, for the period from 2012 to 2019 have been processed. According to IMO CircularMSC-MEPC.3/Circ.3 "Casualty-related matters. Reports on marine casualties and incidents":

"Very serious casualties" are casualties to ships which involve total loss of the ship, loss of life, or severe pollution. "Serious casualties" are casualties to ships which do not qualify as "very serious casualties" and which involve:

- fire, explosion, collision, grounding, contact, heavy weather damage, ice damage, hull cracking, or suspected hull defect, etc., and resulting in: 
- immobilization of main engines, extensive accommodation damage, severe structural damage, such as penetration of the hull under the water, etc., rendering the ship unfit to proceed, or pollution (regardless of quantity); and/or a breakdown necessitating towage or shore assistance [6,7].

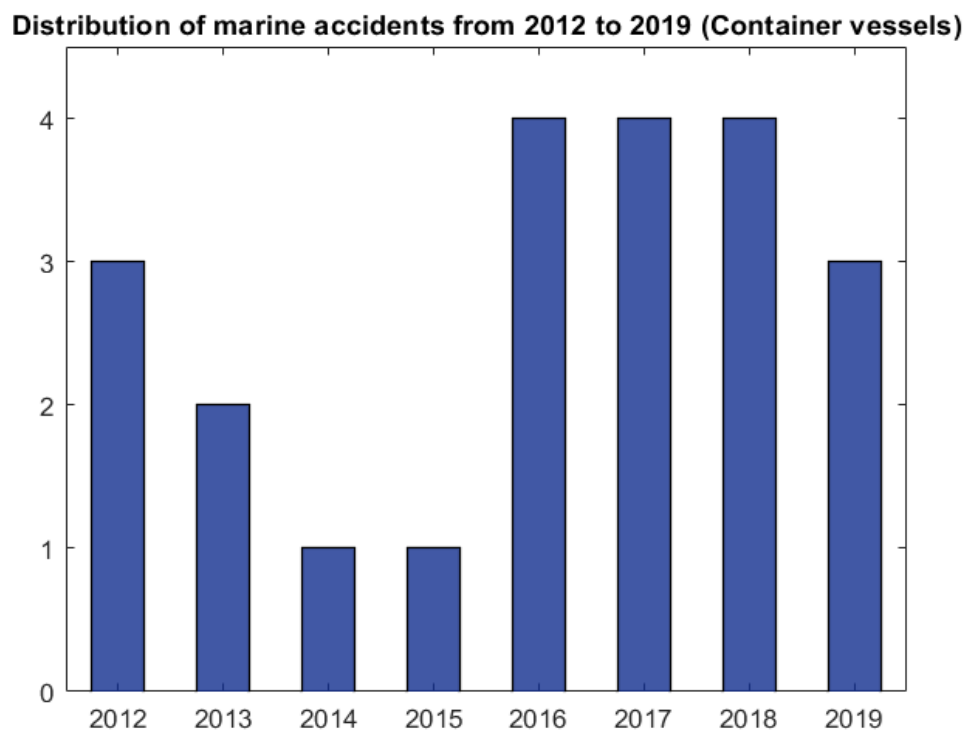

Figure 1. Number of marine accidents -involving container vessels considered in current research (from 2012 to 2019)

Marine accidents considered in the presented analysis are classified as very serious and serious marine casualties. The consequences arising from selected accidents can be grouped as follows:

- four cases that involve vessel foundering, three of them sustaining loss of life;

- fifteen cases which involve severe structural damage to vessel as well as pollution, four between them include human injuries and fatalities;

- fifteen cases which involve severe structural damages to vessel and pollution,

- two cases involving structural damage to vessel and loss of containers;

- one case involving loss of life.

The data provided by the marine investigation reports and EMSA annual overviews $[2,3,4$, $9,11]$ serve as a statistical function. However, the main goal of improving the safety of navigation cannot be achieved through the analysis of statistical data alone. Consequently, the strategy for ensuring the minimization of accidents at sea should consist of identifying the root causes in order to develop the effective methods for their prevention.

\section{Formulation of the goals of the article (problem statement)}

The purpose of this work is to determine the trend of factors leading to marine accidents in container fleet, based on the analysis of marine accidents probability distribution within the period from 2012 to 2019 involving container vessels.

\section{results}

Statement of the material of the study with the justification of the obtained scientific

\section{Details of the analysis data}

The dynamic of incidents probability within the period from 2012 to 2019 was analysed. From the histogram (fig. 1), the increase of the number of accidents starting from 2016 is -evident. Referring to UNTCAD RMT/2017, in 2016 the total demand for shipping services improved, and the world maritime trade volumes expanded by 2.6 percent (from 1.8 in 2015). Containerized trade increased to 3.1 percent in 2016 (from 1.5 in 2015), attaining the volumes of an estimated 140 million TEUs [13]. The slight decrease in 2019 is associated with economic consequences caused by the global COVID-19 pandemic. 
Having examined the investigation reports, the casualties have been categorized according to the type of accident.

The types of accidents covered are listed below:

- Collision - between two or more vessels, between vessel and marine/port structures;

- Fatality (Loss of life) and/or human injury;

- Loss of containers;

- Grounding.

From the histogram illustrated by fig.2, it can be stated that collisions prevail in the area of the analysis. Ship collision is the physical impact that occurs between two (or more) ships or structures resulting in a damaging accident.

In the course of the analysis, the factors leading to accidents have been studied and divided into 9 main groups as follows:

- Lack of situational awareness;

- Over-reliance on Pilot;

- Poor Bridge Resource Management (BRM) performance;

- Lack of safety precautions;

- Poor changeover watch procedure;

- Use of VHF radio communication for collision avoidance;

- Improper use of navigational equipment;

- Inadequate stowage and lashing plan;

- Inappropriate maintenance.

It is important to note that within the selected 22 marine investigation reports, all of the factors leading to marine casualty are related to the human element.

In order to study the trend of factors leading to marine accidents, the root causes were divided into two groups: primary and secondary. The correlation between primary and secondary causes with percentage distribution is shown in fig. 3.

The category "Lack of situational awareness" in this analysis occurs predominantly for both of the causes, primary and secondary. In this paper, the term "Situational awareness" in addition covers some particular actions, such as "assumptions shall not be made on basis of scanty information, especially scanty radar information" [1], maintaining of the proper lookout, and the competency of processing navigational information, including that provided by available decision support tool.

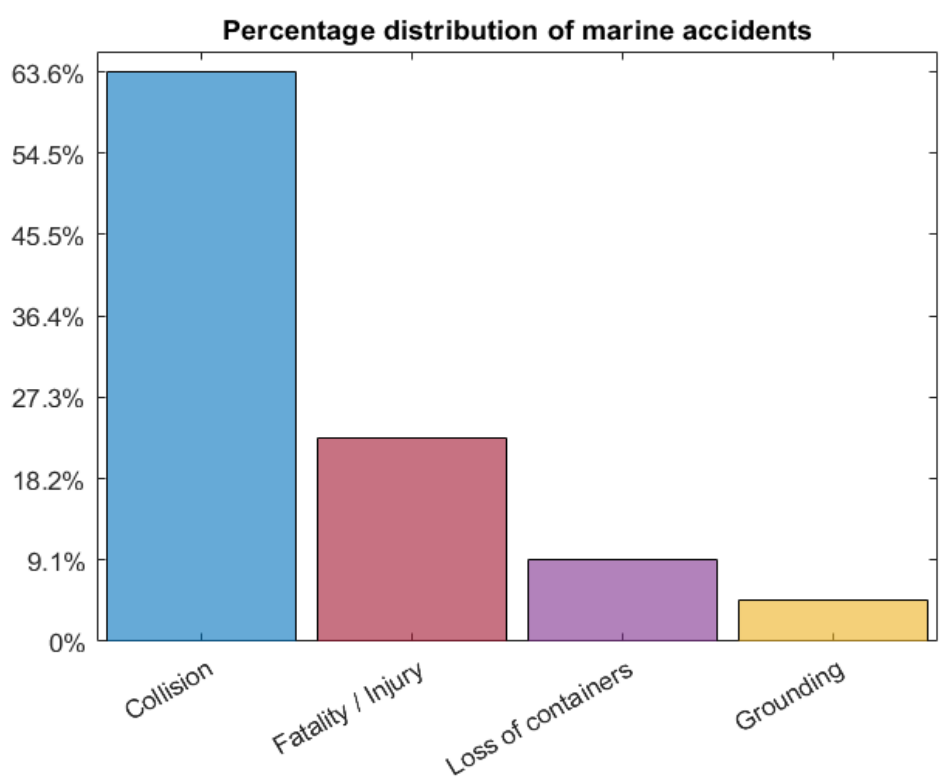

Figure 2. Distribution of marine accidents by type 


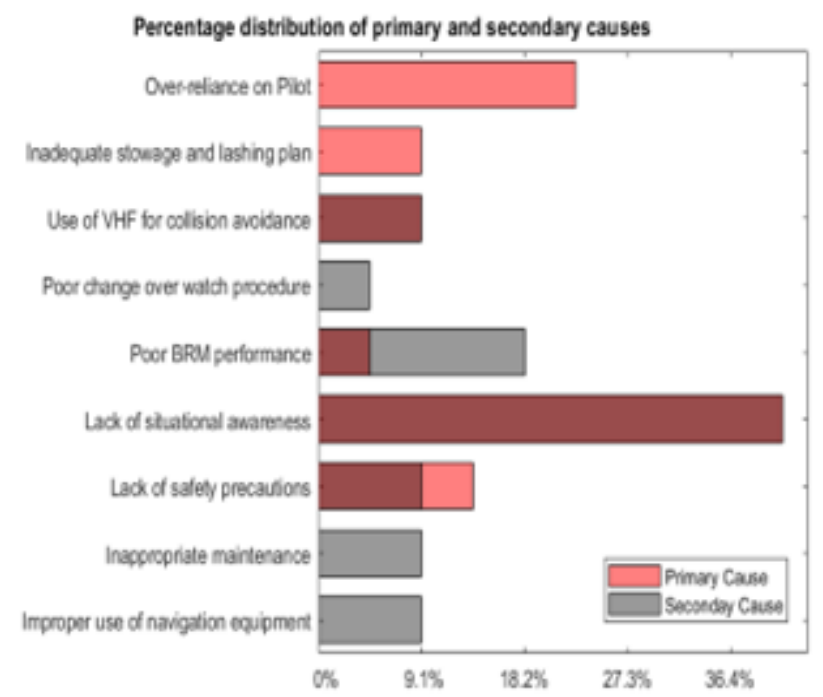

Figure 3. Distribution of primary and secondary causes of marine casualties

\section{General analysis on collisions}

Based on the distribution of the marine accident types, collisions were selected for examination in more detail. The comparison of primary and secondary causes distribution is shown in fig. 4 .

Lack of situational awareness still prevails in both cases, due to the complexity of this term. In concern of the following factors, the close connection can be estimated between over-reliance on Pilot and poor BRM performance. Several marine investigation reports considered in this analysis included complex interaction between navigation with Pilot and incompetent Bridge Resource Management.

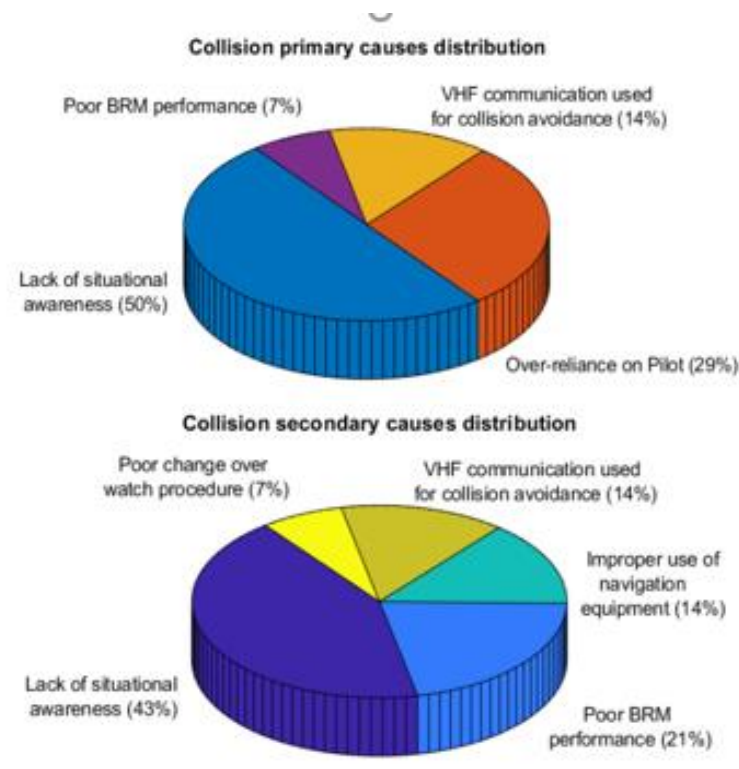

Figure 4. Distribution of primary and secondary causes (Collision)

The other important issue leading to serious accident consequences is the use of VHF radio communication for collision avoidance. The distracting factors in the VHF message exchange can be listed but not limited to:

- vessels identification, especially in darkness, in poor visibility, and in high traffic density;

- time loss for establishing contact via VHF radio instead of taking appropriate action to avoid collision following COLREGs;

- ambiguous messages interpretation due to possible language deviations and uncertain expressions used; 
In respect of the improper use of navigational equipment, it is related to the seafarer's level of competency. While processing statements of facts outlined in marine casualty investigation reports, it appeared quite common for OOW to neglect using the vital functions of ECDIS, Radar, AIS, etc.

In terms of performing change over the watch procedure, the issue revealed was the false confidence in the actions, intentions, and assessment of the situation. The collision accident between container vessel "Sinokor Incheon" and fishing vessel "Toshimaru" occurred in 2016 in Japanese coastal waters. The root causes of the case included an integration of poor changeover watch procedure: OOW left the Navigation Bridge earlier, without properly instructing the relieving officer. The officer, who took over the watch, failed to maintain a proper lookout, which led to the lack of situational awareness. Finally, the above mistakes resulted in the loss of life of the fisherman.

Correlation between primary and secondary causes for collisions is shown in fig. 5. The combination of the main factors, primary and secondary, is characterized by the lack of situational awareness and poor BRM performance.

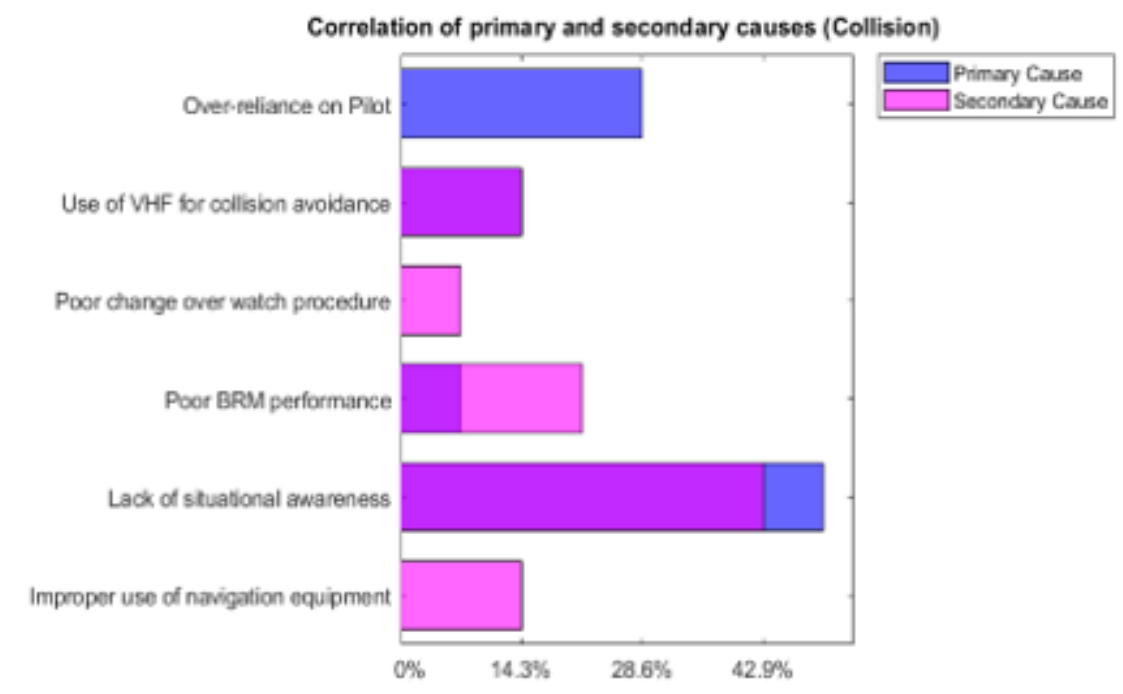

Figure 5. Correlation of the primary and secondary causes (Collision)

\section{Collision of three container vessels - case study}

This paragraph is concerned with the consideration of one of the analysed marine accidents. The main purpose is to find out the main causes of the casualty and damage, thereby preventing future accidents.

The case of concern describes three container vessels that collided on March 21, 2019, in Japanese coastal waters. The container ship “APL Guam” (Vessel A) under pilotage was proceeding north toward her planned anchorage, bounding Keihin Port. The container ship "Marcliff” (Vessel B) was proceeding south-southeast toward Nagoya Port. Both vessels collided in the anchorage area, where Vessel B subsequently collided with the anchored container ship "Hansa Steinburg" (Vessel C). There were no casualties on any of the vessels involved. Weather and sea conditions at the time of the accident were clear, the wind direction was Southwest, the wind force was 5 by Beaufort scale, visibility was more than $5 \mathrm{~nm}$, and the tide was almost low. Taking into concern the statements of fact provided in the marine investigation report, the data analysis is summarized in table 1.

The conditions of lookout and ship maneuvering can be described as follows. Vessel A: Master A and Pilot A observed Vessel B turn to starboard. As vessel A was proceeding north, staying close to Vessel C's side, it was expected that Vessel B would turn to starboard to pass Vessel A port-toport rather than navigate in the narrow sea area between Vessel A and Vessel C. Therefore, vessel A kept proceeding with the same course and speed. Although Master A and Pilot A blew one long blast of the whistle to alert Vessel B, once they recognized the hazard of the close-quarters situation, Vessel B continued to approach Vessel A. Master A ordered OOW A to stop the engine and to set it to full 
astern. It should be highlighted that at the time of the accident, Pilot A had an assurance that vessel B would alter course to starboard.

Table 1. Summary of the data analysis of the collision between container vessels

\begin{tabular}{|l|l|l|l|}
\hline Vessel name & APL Guam (Vessel A) & Marcliff (Vessel B) & $\begin{array}{l}\text { Hansa Steinburg (Vessel } \\
\text { C) }\end{array}$ \\
\hline $\begin{array}{l}\text { Navigational } \\
\text { status }\end{array}$ & Underway by engines & Underway by engines & At anchor \\
\hline Departure port & KR PUS & JP YOK & JP YOK, Anchorage YL4 \\
\hline Destination port & JP YOK, Anchorage YL4 & JP NGO & JP YOK \\
\hline Under Pilotage & Yes & No & No \\
\hline Collision impact & Vessel B & Vessel A and vessel C & Vessel B \\
\hline $\begin{array}{l}\text { Bridge Team } \\
\text { Members }\end{array}$ & $\begin{array}{l}\text { Pilot, Master, OOW, } \\
\text { helmsman }\end{array}$ & $\begin{array}{l}\text { Master, } \\
\text { helmsman }\end{array}$ & OOW \\
\hline $\begin{array}{l}\text { Damage to } \\
\text { Vessel }\end{array}$ & $\begin{array}{l}\text { Dents and abrasions with } \\
\text { a hole in her bow's shell } \\
\text { plating }\end{array}$ & $\begin{array}{l}\text { Dents and abrasions in } \\
\text { her bow's shell plating } \\
\text { and starboard bow's } \\
\text { shell plating }\end{array}$ & $\begin{array}{l}\text { Dents and abrasions with } \\
\text { bow's shell plating }\end{array}$ \\
\hline $\begin{array}{l}\text { Time of } \\
\text { collision hazard } \\
\text { recognition }\end{array}$ & \multicolumn{1}{|c|}{ Around 23:25 Around 23:26 } & Around 23:26 \\
\hline $\begin{array}{l}\text { Date and Time } \\
\text { of the accident }\end{array}$ & $\begin{array}{l}\text { Around 23:27 on March 21, 2019, when the sound of the impact was recorded } \\
\text { on the VDRs of Vessel A, Vessel B, and Vessel C }\end{array}$ \\
\hline $\begin{array}{l}\text { Injuries to } \\
\text { Persons }\end{array}$ & No casualties on Vessel A, Vessel B, or Vessel C \\
\hline Weather, sea & Clear, the wind SW, force 5, visibility > 5 nm, low tide. \\
\hline $\begin{array}{l}\text { Primary cause of } \\
\text { the accident }\end{array}$ & $\begin{array}{l}\text { Lack of situational } \\
\text { awareness }\end{array}$ & $\begin{array}{l}\text { Lack of situational } \\
\text { awareness }\end{array}$ \\
\hline $\begin{array}{l}\text { Secondary cause } \\
\text { of the accident }\end{array}$ & $\begin{array}{l}\text { Over-reliance on Pilot, } \\
\text { Poor BRM performance }\end{array}$ & $\begin{array}{l}\text { Improper use of } \\
\text { navigation equipment }\end{array}$ \\
\hline
\end{tabular}

Vessel B: Master B took a decision to pass between the anchored Vessel C and Vessel D in order to avoid two approaching vessels proceeding southwest of Vessel B's port bow, and Vessel B altered course to starboard. In concern of vessel A, Master B estimated the CPA of 0.2 to $0.3 \mathrm{M}$ if Vessel A maintained her course, passing starboard to starboard.

Vessel C: OOW of Vessel $\mathrm{C}$ observed risk of collision arising from the approach of Vessel A and Vessel B, thus, the whistle from Vessel $\mathrm{C}$ was sounded as a warning.

At the time of the accident, despite VHF communication was not used, the courses intersection and risk of collision occurred. The scheme of routes from the marine investigation report [9] is shown in fig. 6 .

Considering the statement of fact outlined in the investigation report, it can be estimated that situational awareness was not properly maintained. Key timing was stated as 23:23, however, the vessels had to assess the situation well in advance. In the described case the combination of the following factors might be noted:

Vessel A - lack of situational awareness, over-reliance on Pilot, and poor BRM performance;

Vessel B - lack of situational awareness, poor lookout, and improper use of navigational equipment;

None of the vessels was aware of the risk of collision or hesitated in their navigational intentions.

"Rule 7(a) Every vessel shall use all available means appropriate to the prevailing circumstances and conditions to determine if the risk of collision exists. If there is any doubt such risk shall be deemed to exist. [1]" 


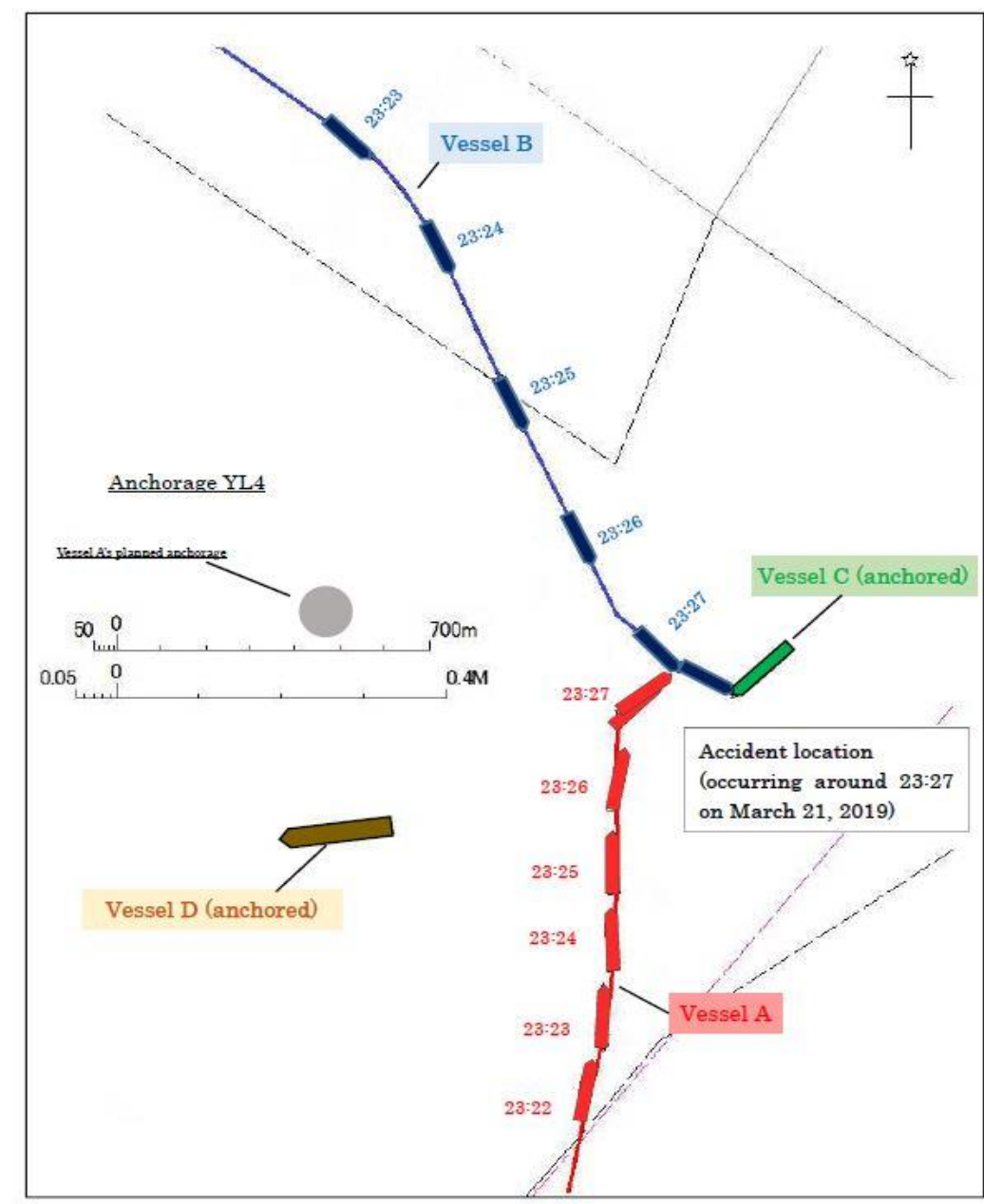

Figure 6. Estimated navigation routes of the Vessels A, B and C

On the one hand, one of the probable actions to avoid a close-quarters situation in the described case could be reducing the speed by one of the vessels. On the other hand, Vessel B faultily estimated that passing between Vessel A and Vessel $\mathrm{C}$ with a Radar CPA of $0.3 \mathrm{~nm}$ could not be considered as a close-quarters situation.

"Rule 8(c) if there is sufficient sea room, alteration of course alone may be the most effective action to avoid a close-quarters situation provided it is made in good time, is substantial and does not result in another close quarter situation.

Rule $8(d)$ Action taken to avoid collision with another vessel shall be such as the result in passing at a safe distance. The effectiveness of the action shall be carefully checked until the other vessel is finally passed clear.

Rule 8(e) if necessary to avoid collision will allow more time to assess the situation, and the vessel shall slacken speed or take off all the way by stopping or reversing the means of propulsion." [1]

Since the marine casualty took place in Japanese coastal waters, Japanese VTS should inform both vessels regarding the intention of the other vessel and issue instructions for keeping a wide berth. The role of the VTS should not be underestimated. IMO Resolution A.857(20) for Vessel Traffic Services [8] recognizes that the level of safety and efficiency of maritime traffic within an area covered by a VTS is dependent upon close cooperation between those operating the vessel traffic service and participating vessels.

"Vessel traffic service (VTS) - a service implemented by a Competent Authority, designed to improve the safety and efficiency of vessel traffic and to protect the environment. The service should have the capability to interact with the traffic and to respond to traffic situations developing in the VTS area." 
VTS should provide three types of services, according to IMO Resolution A.857(20) for Vessel Traffic Services. The information service - by broadcasting information at fixed times and intervals or when deemed necessary by the VTS or at the request of a vessel. The reports and may following information: position, identity, intentions of other traffic; navigation conditions; weather; hazards; or any other factors that may influence the vessel's transit.

The navigational assistance service is provided when the navigational situation is difficult or meteorological circumstances are unfavorable. This service is normally rendered at the request of a vessel or by the VTS when deemed necessary.

The traffic organization service controls the operational management of traffic and the forward planning of vessel movements to prevent congestion and dangerous situations. It is particularly important when traffic density is high and when special transports movement may affect the traffic flow.

When the VTS is authorized to issue instructions to vessels, these instructions should be resultoriented without the details of execution to the master or pilot on board the vessel.

In addition, it should be mentioned that clearly stated voyage data in AIS assists in predicting the intended route of the vessel. In case both vessels (A and B) had entered the actual data and then had checked them, their actions would have been safer, more conscious, and effective in terms of safety of navigation. AIS is a useful source of supplementary information to that derived from navigational systems (including radar) and therefore an important 'tool' in enhancing situation awareness of users. AIS can assist in tracking another vessel as a target. Many of the problems such as clutter, target swap, target loss, etc., do not affect AIS. AIS can also assist in the identification of targets, by name or call sign and by ship type and navigational status.

However, according to Resolution A.1106(29) - "Guidelines for the onboard operational use of shipborne automatic identification systems (AIS)" the following cautionary points should be borne in mind:

"...AIS is an additional source of navigational information. It does not replace, but supports, navigational systems such as radar target-tracking and VTS; and

the use of AIS does not negate the responsibility of the OOW to comply at all times with the Collision Regulations, particularly rule 7 when determining whether risk of collisions exists.

The user should not rely on AIS as the sole information system, but should make use of all safety-relevant information available... [12]"

In the summary of the considered marine investigation report, the implementation of the following preventive measures was declared necessary:

1) Whenever possible, large vessels should avoid situations of courses intersection with other approaching vessels while navigating in anchorage areas confined by anchored vessels.

2) Masters and Pilots should plan their maneuvering intentions in accordance with COLREGs and confirm their passage with respective VTS in due time to provide safe and efficient vessel traffic flow within the area involved.

3) Masters and Pilots should take into consideration the possible risk of collision when navigating nearby anchored vessels, and, if such risk of collision exists, take measures to avoid collision according to COLREGs while sufficient time is available.

4) Respective companies should include into their Safety Management System plans and instructions to prevent similar accidents in the future.

\section{Conclusions and prospects for further work in this area}

Container vessels play a vital role in supply chains and global trade routes. The factors of the increase of the container vessels size, as well as the growth of the container fleet, have a drastic impact on the safety of navigation worldwide.

Based on the results of the presented analysis of the marine accidents involving container ships, it can be summarized that the main root causes are connected with the teams and individuals' erroneous actions and hazardous behaviours. The human element has negatively revealed itself as the negligence of the responsible persons in conducting proper lookout, processing navigational and 
safety information, following COLREGs, exchanging information between vessels' bridge team and Pilot, and gaining situational awareness. Safety recommendations implemented by the investigators in respect of the studied casualties mostly addressed the training and competency examination of the crew involved.

In this respect, the development of crew soft skills such as communication, teamwork and leadership in combination with abilities to critically assess the situation and the quality and the meaning of available data cannot be underestimated when it comes to the accident likelihood reduction.

The perspective of estimating the key factors affecting the neglect of risk assessment during navigation of container vessels has to be studied. The methods to assist the control of safety awareness based on specific navigational and manoeuvring features are to be considered in future researches.

\section{ЛІТЕРАТУРА}

1. Convention on the International Regulations for Preventing Collisions at Sea, 1972 (COLREGs).

2. European Maritime Safety Agency (EMSA): Annual overview of marine casualties and incidents 2020, Lisbon, 2020.

3. European Maritime Safety Agency (EMSA): Preliminary annual overview of marine casualties and incidents 2014-2020, Lisbon, 2021.

4. European Maritime Safety Agency (EMSA): Safety Analysis of Data Reported in EMCIP Analysis on Marine Casualties and Incidents involving Container Vessels, 2020.

5. Hasanspahi'c, N., Vuji 'ci'c, S., Fran “ci'c, V., Campara, L, The Role of the Human Factor in Marine Accidents. J. Mar. Sci. Eng. 2021, 9, 261. [Online]. Available: https://doi.org/10.3390/ jmse9030261

6. IMO, Casualty Investigation Code, London, 2008.

7. IMO Circular MSC-MEPC.3/Circ.3, Casualty-related matters. Reports on marine casualties and incidents, 2008.

8. IMO Resolution A.857(20) for Vessel Traffic Services, 1997.

9. Japan Transport Safety Board Marine Accident and Incident Reports, 2012-2019. [Online]. Available: https://www.mlit.go.jp/jtsb/marrep.html

10. Krzysztof Wróbel, Searching for the origins of the myth: $80 \%$ human error impact on maritime safety, Reliability Engineering \& System Safety, Volume 216, 2021, 107942, ISSN 0951-8320. [Online]. Available: https://doi.org/10.1016/j.ress.2021.107942

11. Marine Accident Investigation Branch Reports, 2012-2019. [Online]. Available: https://www.gov.uk/maib-reports

12. Resolution A.1106(29) - Guidelines for the onboard operational use of shipborne automatic identification systems (AIS), 2015.

13. UNCTAD/RMT/2017, [Online]. Available: https://unctad.org/system/files/officialdocument/rmt2017_en.pdf 